\title{
Situating the Concept of Mindfulness in the Theravāda Tradition
}

\author{
Tamara DITRICH*
}

\begin{abstract}
Mindfulness plays a prominent role in traditional and modern Buddhist meditation practice. This paper examines the theoretical background of the concept of mindfulness (sati) as presented in the early Buddhist sources, recorded in Theravāda Buddhism. It outlines the definitions and presentations of mindfulness (sati) in the Pāli Canon and examines how it is embedded within the fundamental models of Buddhist discourse. Then it investigates mindfulness within the philosophical framework of the Abhidhamma, where it is presented as one of the mental factors (cetasika) involved in cognitive processes; it outlines its characteristics, functions, conditions, and compatibility with other mental factors, which occur as components within the interdependent processes of consciousness (citta). The article shows how mindfulness has a special role as a component on the Buddhist path to liberation from suffering $(d u k k h a)$ and how it is integrated within the soteriological and ethical goals of Buddhist practice.
\end{abstract}

Keywords: mindfulness, sati, early Buddhism, ethics and Buddhist meditation, Buddhist psychology

\section{Izvleček}

Čuječnost ima pomembno mesto v tradicionalni in moderni budistični meditaciji. Prispevek preučuje teoretične osnove in izhodišča koncepta čuječnosti (sati) v zgodnjih budističnih virih theravādskega budizma. Najprej opiše definicije in predstavitve čuječnosti (sati) v pālijskih kanoničnih besedilih in prikaže, da je čuječnost sestavni del vseh glavnih modelov budističnega diskurza. Nato raziskuje čuječnost v filozofskem okviru Abhidhamme, kjer je predstavljena kot eden od mentalnih dejavnikov (cetasika), udeleženih $\mathrm{v}$ kognicijskih procesih, ter oriše njene glavne značilnosti, funkcije in povezave $\mathrm{z}$ drugimi, soodvisnimi komponentami kognicije (citta). Prispevek prikaže, na kakšen način je čuječnost integralni del soterioloških in etičnih ciljev budistične prakse, ki naj bi prepeljala do osvoboditve od trpljenja in nezadovoljivosti bivanja (dukkha).

Ključne besede: čuječnost, sati, zgodnji budizem, etika in budistična meditacija, budistična psihologija

Tamara, DITRICH, Research Fellow, University of Ljubljana,

Nan Tien Institute, and University of Sydney

t.ditrich[at]gmail.com

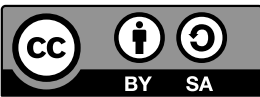




\section{Defining Mindfulness}

The word "mindfulness" is the English translation of the Pāli term sati ${ }^{1}$ (Sanskrit smrti), which refers to an important concept in Buddhist doctrine and a central component of Buddhist meditation. The term was rendered into English as mindfulness in the 1880s, firstly introduced by T. W. Rhys Davids in his translations of the Pāli Canonical texts (Gethin 2011, 263-4). Since then, the term has become well established in English translations of Buddhist literature and, later on, started to refer primarily to a particular meditation method. The Pāli term sati is attested in a range of meanings such as "memory, recollection, recognition, mindfulness, wakefulness, alertness." Although the Sanskrit equivalent smrti is most commonly translated as "memory," it seems that already in the earliest Vedic texts the term encompassed a range of connotations similar to those in Buddhist contexts (i.e., "memory, attention, awareness"), as convincingly argued by Klaus (1992, 77-86). The semantic scope of this term is rather wide and, consequently, its English translation has not been fully standardised. ${ }^{4}$

In the Pāli Buddhist Canon, the term sati occasionally refers to remembering past events ${ }^{5}$ and, more often, in meditation contexts, to the recollection (anussati) of wholesome objects such as the qualities of the Buddha. ${ }^{6}$ However, most frequently, sati refers to meditative awareness, rendered into English as "mindfulness", often attested in conjunction with the term "clear comprehension" (sampajañ $a)$. The predominant occurrences of sati in meditation contexts reflect the main aims of the Buddhist teachings presented in the Pāli Canon, which largely focus on the soteriological goals to be achieved through ethical and meditative training; hence, the Buddhist doctrine is not much concerned with the mundane events or their remembrance. Although the conditions for recollective memory and mindful awareness are linked within the semantic range of sati, as discussed

1 Interpretations of mindfulness that have evolved in modern Buddhism very frequently refer back to Theravāda sources. The overview of the concept of mindfulness in this article therefore draws from the Theravāda Buddhist canon, with the technical terms for mindfulness and the related concepts given in Pāli.

2 Pāli sati is rendered in PED (s.v.) into English as "memory, recognition, wakefulness, mindfulness, alertness".

3 Sanskrit smrti is translated in MW (s.v.) as "remembrance, reminiscence, calling to mind, memory".

4 A good overview of the concept of memory in different Buddhist textual traditions and various contexts is given in Gyatso (1992).

5 AN V 145.

6 E.g., the recollections (anussati) listed in the Visuddhimagga (Vism 197-228) include remembering of the qualities of the Buddha, the Dhamma, the Sangha, virtues, generosity and deities. 
by several scholars (Cox 1992, 67-108), sati occurs in the Pāli Canon primarily as a meditational term.

In the Pāli Canon, sati is often described as a particular kind of remembering, indicating non-forgetfulness, wakefulness, presence; for example, in the Dhammasangani, the faculty of mindfulness (satindriyam) is defined as: "... remembering, recollection, mindfulness as memory, bearing in mind, not wobbling, not forgetting; mindfulness as faculty, power, right mindfulness ... «. ${ }^{7}$

Non-forgetfulness refers to mindful attention towards meditation objects from an ethical perspective - as to whether the objects are wholesome or not; hence, Gethin $(2011,265)$ describes sati as a kind of "ethical intuition". The function of ethical watchfulness of sat $i$ is illustrated in many texts through similes such as the well-known comparison of mindfulness to a gatekeeper who is guarding the city's six gates (representing the six senses) from strangers (i.e. unwholesome mental states). ${ }^{8}$ In the Visuddhimagga, Buddhaghosa summarises the characteristics and functions of mindfulness in the following passage:

By [mindfulness] they remember (saranti), or it remembers by itself, or it is just only remembering (sarana), this is mindfulness (sati). Its characteristic is not wobbling (apilappana), its function is non-confusion, it is manifested as guarding, or as facing the object. Its proximate cause is firm perception (thirasañ $\tilde{\bar{a}})$, or its proximate cause is the foundation of mindfulness of the body, and so on (kāyādisatipatțhanna). Because it is firmly supported, it should be viewed as a pillar, or as a gate-keeper because it guards the eye-door, and so on. ${ }^{9}$

This definition and characterisation of mindfulness has often served as a foundation for its interpretations in modern Buddhism from the late nineteenth century onwards, particularly in Burmese Buddhism, where meditation was positioned at the centre of Buddhist teachings and thus provided the grounds and conditions for the subsequent popularisation and secularisation of mindfulness in the late twentieth century (Braun 2013).

7 Dhs 11; 16: ... anussati patissati sati saranatā dhāranatā apilāpanatā asammussanatā sati satindriyam sati balam sammāsati .... All translations from Pāli into English are by the author of this paper (Cf. Rhys Davids 2012,14).

8 SN IV 194.

9 Vism 464: Saranti tāya, sayam vā sarati, saraṇamattam eva vā, esā ti sati. Sā apilāpanalakkhaṇā,

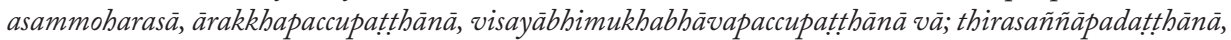
kāyādisatipațthānapadațthānā vā. Arammane daḷapatițthitattā pana esikā viya, cakkhudvārādirakkhaṇato doväriko viya ca datțhabbā. (Cf. Ñāṇamoli 1994, 524) 
As indicted by Buddhaghosa in the passage above, mindfulness is a wakeful, ethical guarding, a gate-keeper for the cognitive processes arising through the six senses, and thus serves as a foundation for meditative cultivation $(b \bar{a} \bar{v} a n \bar{a})$. Its proximate cause or condition are the four foundations of mindfulness, the four satipatthanas. ${ }^{10}$ There are several texts in the Tipitaka ${ }^{11}$ that describe or prescribe the practise of the four satipatthannas; the longest and most detailed ones are the two versions of the Satipatthanasutta. ${ }^{12}$ In the beginning of this sutta mindfulness is clearly situated as a component of meditation training, prescribing how a monk should practice it:

A monk abides contemplating the body as a body, diligent ( $\bar{a} t \bar{a} p \bar{\imath})$, clearly comprehending (sampajāno) and mindful (satimā), having abandoned desires and discontent (vineyya abhijjhädomanassam) regarding the world $($ loke $) .{ }^{13}$

The same formula is repeated for contemplation of the body (käya), feelings (vedan $\bar{a}$ ), the mind (citta), and mental phenomena (dhamma). Mindfulness is to be practiced in conjunction with other qualities: the meditator needs sustainable effort or diligence ( $\bar{a} t \bar{a} \bar{p} \bar{\imath}$ ), explained in the Buddhaghosa's commentary, the Papañcasīdani, as the energy required to burn defilements (kilesa). ${ }^{14}$ Another quality to accompany mindfulness is clear comprehension (sampajañna), which is presented in several passages in the canonical texts; it functions as an understanding that conditions cultivation of wholesome qualities and abandons those that are unwholesome. ${ }^{15}$ In the Dhammasangani, clear comprehension (sampajañana) is defined as the faculty of wisdom (pañ $\tilde{a})$, which encompasses understanding, insight, analytical discrimination, wise reflection, etc. ${ }^{16}$ The practise of the four satipatthanas

10 Vism 464; the four satipatthānas include mindfulness of the body (kāya), feelings (vedanā), the mind (citta) and mental phenomena (dhamma).

11 The following are identified in the Suttapitaka (by the Digital Pali Reader); AN III 450; DN II 290-315; MN I 55-63; MN III 111-2; SN V 143, 294-7; Nidd 1 1, 28, 63, 72, 78, 99; 340, 354, 370, 387; Nidd 2 78, 124, 128.

12 I.e. the Satipatthānasutta in the Majjbima Nikāya (MN I 55-63) and the Mabāsatipațthānasutta in the Digha Nikāya (DN II 290-315).

13 MN I 56; DN II 290: àtāpi sampajāno satimā vineyya loke abhijjhādomanassam.

14 Ps I 244: àtāpiti tìsu bhavesu kilese àtāpetīti àtāpo.

15 AN I 13.

16 Dhs 16: Katamam tasmim samaye sampajañnam hoti? Yã tasmim samaye paññā pajānanā vicayo pavicayo dhammavicayo sallakkhaṇa upalakkhaṇa paccupalakkhaṇa paṇdiccam kosallam nepuññam ve-

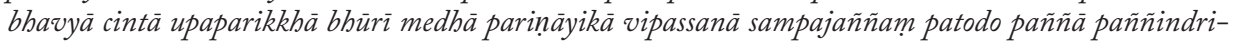
yam paññābalam paññāsattham paññāpāsādo pañña-āloko pañña-obhāso paññāpajjoto paññāratanam amoho dhammavicayo sammädițthi-idam tasmim samaye sampajañnam hoti. The same definition is given in Dhs 11 for paññindriyam. (Cf. Rhys Davids 2012, 16) 
also requires that the meditator has overcome (vineyya) desires and discontent ( $a b$ bijjbadomanassam) concerning the world (loke). The world refers to the body, the feelings, the mind and phenomena, ${ }^{17}$ or in other words, according to the Vibhanga, the five aggregates of clinging which represent the world of experience. ${ }^{18}$

Thus, mindfulness (sati) is not practised on its own but in conjunction with other qualities, such as wisdom, and requires (temporary) absence of desire and aversion. As will be discussed later on, sati is presented in the Pāli Abbidhamma as one of the universal wholesome or ethical (kusala) mental components (cetasika) and, consequently, it can occur only in the company of other wholesome components. Hence, it is not compatible with aversion, desire, delusion and other unwholesome or ethically unskilful mental components (akusala cetasika). Mindfulness, together with other components, can see and understand unwholesome conditions for objects that may arise; however, the process of cognition itself of the object is wholesome when mindfulness is present. Thus in the practise of the four satipatthanas the focus is not only on what is experienced (although the object itself is conditioned and conditioning other components within cognitive processes) but primarily on how the object is cognised, which depends on the cetasikas accompanying cognition: if mindfulness is present in the cognition (citta), then the cognition itself is wholesome, ethical and provides the necessary conditions for knowledge, clear comprehension (sampajañna) or wisdom (pañ $\tilde{a})$ to arise.

Mindfulness is firmly embedded and integrated within the doctrinal structure of the Pāli Canon, which is underpinned by the fundamental premise that non-satisfactoriness and suffering $(d u k k h a)$ of human existence-as a response to life experiences - can be completely overcome or transcended through ethical and meditation training, leading to insight or wisdom (pañña) and, ultimately, to nibbāna. The term pañña is usually translated into English as wisdom, intuitive understanding, or an insight into the nature (i.e. impermanence, non-satisfactoriness and non-self) and conditionality of all mental and physical phenomena comprising human experience. It is presented as a component in cognitive processes which directly sees the experiences as a flow of momentary, interlinked and impersonal phenomena and conditions. It is described as discriminative knowledge, intuitive intelligence, absence of delusions, right view, ${ }^{19}$ and is often linked to or

17 Ps I 244: loketi tasmimyeva kāye. kāyo hi idha lujjanapalujjanațthena lokoti adhippeto.

18 Vibh 195: pañca pi upādānakkhandhà loko: ayam vuccati loko.

19 Dhs 11: katamam tasmim samaye paññindriyam hoti? yä tasmim samaye paññā pajānanà vicayo pavicayo dhammavicayo sallakkhaṇā upalakkhañā paccupalakkhaṇā pandiccam kosallam nepuññam vebhabyā cintā upaparikkhā bhūrī medhā parināyikà vipassanà sampajaññam patodo paññā paññindriyam paññābalam paññāsattham paññāpāsādo paññāāloko paññāobhāso paññāpajjoto paññāratanam amoho dhammavicayo sammādițthi — idam tasmim samaye paññindriyam hoti (Cf. Dhs 12; 13; 14). 
equated with clear comprehension (sampajañna) ${ }^{20}$ In the Visuddhimagga the term pañ $\tilde{a} \bar{a}$ is explained in the following way:

Pañ ña is insight knowledge (vipassanānānama), associated with wholesome cognition (kusalacitta) ... it is knowing (jänana) which is different from perceiving (sañjānana) and cognizing (vijānana) ... Pañ ña knows the object, bringing up understanding of the characteristics (lakkhanapativedha). ${ }^{21}(\text { Vism XIV }, 3)^{22}$

The attribute kusala, usually rendered into English as "wholesome, skilful, good, right", ${ }^{23}$ refers here to those components involved in cognitive processes that are skilful, ethically wholesome or appropriate for the path to liberation from suffering $(d u k k h a)$. All such ethical or wholesome states, free from delusion, desire and aversion, are viewed as states of mental health, ${ }^{24}$ which is presented as the foundation and necessary condition for knowledge or insight to arise. According to the Abhidhamma, wisdom always arises in conjunction with mindfulness (sati), which can in turn only occur in the "good company" of other ethical components (kusalacetasika) of cognition (citta).

To summarise, mindfulness is presented in the Pāli Canon in conjunction with several other mental components or qualities that are to be cultivated together in meditative training, aiming to develop wisdom and liberation from suffering. Although this paper does not aim to discuss or compare Buddhist presentations of mindfulness with its contemporary interpretations in new secular contexts, ${ }^{25}$ it will briefly touch upon some relevant issues. It may be argued that the presentation of mindfulness in the Buddhist context is significantly different-in its definition, aims, characteristics, functions and the entire underpinning discoursefrom its modern definitions and secular applications. In the new secular contexts, mindfulness is to a large extent perceived as a therapeutic tool, helpful for a wide

20 Dhs 16.

21 Here the text refers to the three characteristics (tilakkhana): impermanence (anicca), non-satisfactoriness (dukkha) and non-self (anattā).

22 Vism 436-7: Kusalacittasampayuttam vipassanānāṇam paññā... Sañjānana-vijānanākāravisitțham nānappakärato jānanam. ... Pañ̃nā vuttanaya-vasena ärammaṇañ ca jānāti, lakkhaṇapativedhañ ca päpeti.

23 PED, s.v.

24 As 62-63: kilesāturatāya kilesagelaññassa ca kilesabyādhino abhāvena ārogyatțhena kusalam veditabbam ... kilesavajjassa pana kilesadosassa kilesadarathassa ca abhävã anavajjațthena kusalam. (Cf. Tin 2013, 83).

25 A number of papers has been published in the last decades, exploring modern interpretations of mindfulness; e.g., Sharf 1995; Gethin 2011; Kirmayer 2015; Ditrich 2016. 
spectrum of problems and disorders, or for enhancing general well-being. It is typically defined in its new functions as "the awareness that emerges through paying attention on purpose, in the present moment, and non-judgementally" (Kabat-Zinn 2003, 145). The common denominator of the new definitions of mindfulness is non-judgemental attention to the present moment. Within the Buddhist doctrinal models of cognition, the closest correlative concept for this new interpretation of mindfulness would be the term manasikara, usually rendered into English as "attention" ${ }^{26}$ According to the Abhidhamma, manasikāra is one of the mental components, present in every moment of cognition (citta); it may arise in conjunction with ethically wholesome, unwholesome or neutral mental states. In the Visuddhimagga, it is defined as:

... the maker in the mind (manambi käro) ... the supporter of the object (ārammanapatipädako), the supporter of cognitive processes (vithipatipādako) and the supporter of apperception (javanapatipädako)... Its characteristic is directing (särana), its function is bonding (samyojana) associated states to the object, its manifestation is facing an object (ârammañäbimukha) and its proximate cause is an object. ${ }^{27}$

In the Pâli Canonical texts, attention is presented in two distinct modes: it can be skilful, wise attention (yoniso manasikāra) or non-skilful, non-wise attention (ayoniso manasikara). In the context of Buddhist path of ethical and meditational training, only wise attention is to be cultivated, in conjunction with other wholesome components such as mindfulness, whereas unwise attention should be averted from and overcome; for example, in the Sabbassavasutta it is explained that through wise attention (yoniso manasikära) the deepest defilements (äsava) can be extinguished. ${ }^{28}$

In distinction to modern understanding of mindfulness as paying attention non-judgementally, meditation training in the Buddhist teachings does not aim to develop attention on its own but only cultivation of skilful, wise attention (yoniso manasikarra), i.e. attention that is accompanied by other skilful components of cognition, allowing wisdom to be present. In other words, as stated in the Dhammasangani, skilfulness in attention is equated to "wisdom, understanding, non-delusion, wise discrimination, right view." 29

\section{PED, s.v.}

27 Vism 466: Kiriyākāro, manambi kāro manasikāro ... ārammanapațipādako, vīthipațipādako, javanapatipādako ... So sāraṇalakkhaṇo, sampayuttānam ārammaṇe samyojanaraso, àrammaṇābhimukhabhāvapaccupațthāno, àrammaṇapadațthāno.

28 MN I 7-2.

29 Dhs 229: Tattha katamā manasikārakusalatā? Yā tāsam dhätūnam manasikākusalatā pañãā pajānanā ... amoho dhammavicayo sammādițthi--ayam vuccati manasikārakusalatā. 
Furthermore, wise attention (yoniso manasikära) is directly linked to mindfulness (sati). For example, in the Anguttara Nikaya (Yamaka-Vagga) it is said that when wise attention (yoniso manasikära) is achieved, mindfulness (sati) and clear comprehension (sampajañ na) are accomplished; these two being accomplished lead in turn to sense restraint (indriyasamvara), which leads to ethical conduct (tinni sucaritāni), the establishment of the four foundations of mindfulness (cattāro satipatt thāna ), to seven factors of awakening (satta bojjhang $\bar{a}$ ), and to the knowledge and final liberation (vijjävimutti). ${ }^{30}$ Thus, definitions, interpretations and practical applications of mindfulness (sati) in the Pâli Canon are embedded in all the main domains of Buddhist ethical and soteriological discourse.

\section{Positioning of Mindfulness in the Main Doctrinal Models in the Suttapitaka}

Buddhist teachings are succinctly presented through the "four noble truths", which encompass pragmatic, ethical and epistemological aspects of the doctrine. ${ }^{31}$ The four truths outline non-satisfactoriness of existence (dukkba), identifying craving $(\tan h \bar{a})$ as its cause, pronouncing the possibility that one can be completely liberated from suffering (through nibbanna), and outlining the eightfold path, which leads to liberation. The four truths are presented in the Tipitaka through several interrelated models which, from various perspectives, delineate and articulate Buddhist doctrine; they all situate mindfulness (sati) as one of their integral components.

The first truth defines non-satisfactoriness of existence $(d u k k b a)$ as a way of response to experiences, stemming from ignorance about the impermanent nature of all mental and physical phenomena (anicca) and absence of any intrinsic self or identity (anattā). In the Dhammacakkappavattanasutta, non-satisfactoriness $(d u k k h a)$ is described as experiences of:

... birth, aging, illness, death; to be connected to unpleasant circumstances and separated from pleasant ones; not to get what one wants;

30 AN V 115: yonisomanasikāro paripüro satisampajaññam paripüreti, satisampajaññam paripüram indriyasamvaram paripüreti, indriyasamvaro paripüro tīni sucaritāni paripüreti, tīni sucaritāni paripürāni cattāro satipațthāne paripürenti, cattāro satipațțānà paripürā satta bojjhañge paripürenti, satta bojjhangea paripürā vijjāvimuttim paripürenti.

31 According to the tradition, the Buddha explained the four truths already in the Dhammacakkappavattanasutta (SN V 420-424), which is considered to be his first sermon. 
in short, non-satisfactoriness $(d u k k h a)$ is clinging to the five aggregates (pañcupādānakkhandhā). ${ }^{32}$

The five aggregates or five groups of conditions and events, which comprise physical and mental phenomena of existence, are described as: (1) materiality (rüpa), encompassing physical or material components; (2) feelings (vedan $\bar{a}$ ), which occur at every moment of cognition and may be pleasant, unpleasant or neither; (3) perception (sañ $\tilde{a} \bar{a}$, which recognises and labels experiences; (4) numerous mental formations (sai்khära), which arise together with cognition itself and determine how an object is cognised, e.g., with desire, compassion, equanimity, etc.; and (5) cognition (viñ̃āna), which arises at any of the six sense-doors and knows the object of experience. ${ }^{33}$ The five groups or aggregates (khandha) are comprised of interrelated material and mental components participating in the flow of experiences, which we identify with and perceive as a person. They represent the most prominent aspects of experience and each component may be an object of mindful contemplation. Thus, the Satipatţānasutta describes or prescribes ${ }^{34}$ contemplation of impermanence of the five aggregates as an area of mindfulness practise, within the section on contemplation of mental phenomena (dhammas). ${ }^{35}$ Development of mindfulness of the five aggregates is considered to enhance and condition the arising of insight into their impermanent nature (anicca), non-satisfactoriness $(d u k k h a)$, and absence of intrinsic self or identity (anatt $\bar{a})$ - an insight which in turn leads to liberation (nibbāna). ${ }^{36}$

Although there are numerous components involved in cognitive processes, ${ }^{37}$ one is singled out in the context of the second truth about the origination of suffering, namely, craving or desire (tainha $)$, which is considered to be the cause of non-satisfactoriness or suffering $(d u k k h a)$. Hence, only through overcoming this craving is one liberated from ignorance and, consequently, from suffering. Craving is positioned as a component in the formula of interdependent origination (paticcasamuppāda), perhaps the most important model of Buddhist doctrine, discoursed

32 S V 421: Jāti pi dukkhā jarā pi dukkhā vyādhi pi dukkhā maraṇam pi dukkham sokaparidevadukkhadomanassupāyāsāpi dukkhā appiyehi sampayogo dukkho piyehi vippayogo dukkho yam piccham na labhati tam pi dukkham samkkittena pañcupädānakkhandhä pi dukkha.

33 For discourses on the five aggregates, see the Khandhavagga, SN III; English translation by Bodhi (2000, 853-983).

34 Scholars have different views as to whether Buddhist texts on meditation are of descriptive or prescriptive nature (Cf. Sharf 1995, 228-83).

35 MN I 61; DN II 301-2.

36 SN III 1-5; 16-25.

37 The Abbidhamma lists fifty-two mental components (cetasikas) that can occur in various combinations together with every moment of cognition; for the list of cetasikas, see Bodhi 1993, 79. 
upon in numerous Canonical texts and commentaries, expressing the four truths in a dynamic manner. ${ }^{38}$

The formula of dependent origination (paticcasamuppāda) is comprised of the following twelve links in a manner that each conditions the following one:

(1) ignorance $(a v i j j \bar{a}) \rightarrow(2)$ mental formations (sai்khära) $\rightarrow$ (3) cognition or consciousness (viññana) $\rightarrow$ (4) the mind and the body (nämarüpa) $\rightarrow$ (5) sense bases (five physical senses and the mind, and their objects) (salāyatana) $\rightarrow$ (6) contact with objects or experiences (phassa) $\rightarrow(7)$ feelings (pleasant, unpleasant or neutral) (vedana $) \rightarrow(8)$ craving $($ taìh $\bar{a}) \rightarrow(9)$ clinging (upādāna $) \rightarrow(10)$ being $($ bhava $) \rightarrow(11)$ birth $(j \bar{a} t i) \rightarrow(12)$ aging and death (jarāmarana).$^{39}$

This formula describes interlinked conditionality for the arising of suffering $(d u k k h a)$ and rebirth; in reverse order (patiloma), it presents the way to liberation from suffering. The formula is not to be interpreted in a linear manner since all components are interlinked and interdependent. In the process of cognition, consciousness (link 3 ) which arises every moment, is conditioned by past mental formations (link 2), i.e., past conditions and reactions, stemming from ignorance (link 1); here, ignorance refers to not knowing that all the phenomena, conditions, and processes are impermanent, subject to suffering and without an intrinsic self or, in other words, not knowing the four truths. ${ }^{40}$ The process of cognition takes place within the framework of the body and mind (link 4), ${ }^{41}$ which is repeatedly in contact (link 6) through its six senses, with their objects (link 5) ${ }^{42}$ and experiences, which in turn condition the feelings (link 7). Feelings can be pleasant, unpleasant or neither, depending on past conditions and responses (link 2) to similar experiences. The first seven links are interpreted as unavoidable results of the past, which conditions the experience of the present.

If mindfulness and clear comprehension are not present in the cognitive process, one responds to feelings (link 7) with craving (link 8) to keep pleasant experiences or get rid of the unpleasant ones; or in other words, craving for sensual

38 For discourses on causation, see the Nidannavagga, SN II 1-133; D II 55-71.

39 SN II 1-2: Katamo ca bhikkhave paticcasamuppādo? Avijjäpaccayā bhikkhave saìkhārā, sañkhāra-

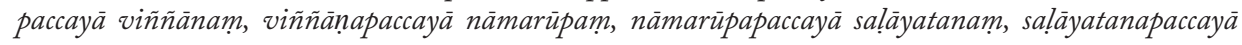
phasso, phassapaccayā vedanā, vedanāpaccayà taṇhā, taṇha paccayà upādānam, upādānapaccayà bhavo, bhavapaccayā jāti, jātipaccayā jarāmaraṇam.

40 SN II 4: Katamā ca bhikkhave avijjā? Yam kho bhikkhave dukkhe añ̃ānạn dukkhasamudaye aññānam dukkhanirodhe aññaṇam dukkhanirodhagāminiyā pațipadāya añāanam. Ayam vuccati bhikkhave avijjā.

41 Consciousness (link 3) and the mind and body (link 4) condition and are conditioned by each other (cf. DN II 32); the two links represent the five aggregates, discussed earlier in this paper.

42 The six sense bases include the five physical senses and the mind, and their corresponding objects. 
pleasures, for being and for not being, which is the origin of suffering. ${ }^{43}$ Craving in turn leads to clinging (link 9), ${ }^{44}$ and consequently, to developing certain ways of being or living (link 10), repeated births (link 11), bringing about aging, death, and non-satisfactoriness (link 12). This in turn generates further ignorance (link 1) about the impermanent nature and emptiness of phenomena, creating new mental formations (link 2), which condition future experiences. The stronger the clinging (link 9), the greater the ignorance (link 1), as well as mental habits and reactions (link 2), which condition and perpetuate new responses to experiences (links 8-10).

The aim of the Buddhist praxis can be articulated as a disentanglement from the web of interdependent origination. One of the key conditions for the reversal of the order of its links is mindfulness, which protects one from responding to continuously arising feelings (link 7) with craving (link 8) and clinging (link 9). The importance of mindfulness of feelings is reflected in the texts on the practise of the four foundations of mindfulness (cattäro satipattāna); for example, in the Satipatthanasutta, ${ }^{45}$ one whole section is dedicated to the contemplation of feelings (vedanānupassanā), ${ }^{46}$ as well as a subsection under contemplation of mental components (dhammänupassanā) ${ }^{47}$ which focuses on the impermanent nature of feelings.

As presented in the formula of dependent origination, mindfulness protectsby its mere presence-from craving and conditions arising of wisdom (pañ $\tilde{a} \bar{a}$ ), which in turn prevents ignorance (link 1) to arise. Wisdom (pañ ña) understands the feelings "as they are" (yathā bhütam), i.e., impermanent, momentary, empty of intrinsic identity. ${ }^{48}$ Since mindfulness and wisdom are mental factors (link 2), by their very nature they are not different from any other phenomena or components of experience - they are also impermanent, empty, and can be subject to suffering when clung to. This insight into the nature of all phenomena leads to the liberation from ignorance (link 1). Complete uprooting of ignorance is presented in the third truth as "blowing away" (Pāli nibbāna, ${ }^{49}$ Sanskrit nirvāna $)$, extinction of suffering, the possibility of attaining the state of nibbanna, which is unconditioned, not subject to change and non-satisfactoriness.

43 MN I 48-49: kāmatạnhà bhavataṇhā vibhavatạnhā, ayam vuccat' àvuso dukkhasamudayo.

44 Four kind of clinging are listed in SN II 3: to sensual pleasures (kāmupādāna); to views (dițthupādā$n a)$; to rules and rituals (sìlabbatupādāna); and to belief in self (attavädupädāna).

45 MN I 55; DN II 290.

46 MN I 59; DN II 298.

47 MN I 61; DN II 301-2.

48 Cf. Vism 436-7.

49 For discussion on the semantic range of the term nibbāna, see PED (s.v.). 
According to the fourth truth, this liberation can be achieved by following the eightfold path, divided into three interlinked sections: wisdom, ethics and meditation. Wisdom (pañ $\tilde{a})$ is presented by two components, right ${ }^{50}$ understanding (samma dittthi) and right intention (sammã saíkappa). Here, right understanding (samma ditthi) refers to direct insight into the nature of all phenomena and their independent conditionality, ${ }^{51}$ or, in other words, understanding of the four truths. ${ }^{52}$ Right intention (samma sankappa) is a resolve to cultivate wholesome mental states, without anger or cruelty, and develop renunciation. ${ }^{53}$ These two are further interlinked with the second group of the eightfold path, which is concerned with ethics (sìla), comprising right speech (sammā-vāca ), right action (sammā kammanta), and right livelihood (sammā ājiva), i.e., it focuses on the speech and way of life that are not harmful to oneself or others. ${ }^{54}$ The ethical components of the eightfold path are conditioned as well as conditioning the first two (pañ $\tilde{n} \bar{a})$ and the last three, concerned with meditation practice (samädhi).

The meditation section comprises: right effort (sammā vāyāma) to develop and maintain ethical (kusala) mental states, and avoid and undercut non-ethical ones (akusala); ${ }^{55}$ right mindfulness (sammā sati); and right concentration (sammā samā$d h i$ ), which focuses on a chosen object of contemplation, leading to deep states of absorption (jhāna). ${ }^{56}$ As it was discussed above, right mindfulness (sammā sati) is defined as ethical attention directed to the ever-changing flow of interrelated physical and mental phenomena or events. ${ }^{57}$

Among the various structural representations of the Buddhist teaching, one of the most pragmatic ones, focusing on mindfulness, is the model of the four

50 PED (s.v.) gives the following English equivalents for the Pāli term samme "thoroughly, properly, rightly, in the right way, perfectly"; in the context of the eightfold path it refers to the development of its components "appropriately" - for achieving liberation from non-satisfactoriness or suffering $($ dukkha).

51 MN I 46-55.

52 Vibh 235: Dukkhe ñānam dukkhasamudaye ñänam dukkhanirodhe ñānam dukkhanirodhagāminiyā pațipadāya ñannam: ayam vuccati sammādițthi.

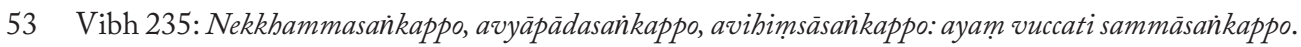

54 Vibh 235: Musāvāà̃ veramaṇi, pisuṇāya vācāya veramaṇī, pharusāya vācāya veramaṇī, samphap-

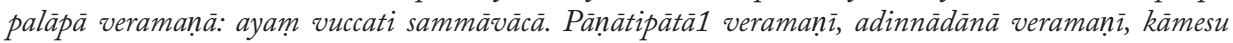
micchācārā veramaṇi: ayam vuccati sammākammanto. Idha ariyasāvako micchā-ājìvam pahāya sammā-äjìvena jìvitam kappeti: ayam vuccati sammāa-àjìvo.

55 Vibh 235: idha bhikkhu anuppannānam pāpakānam akusalānam dhammānam anuppādāya chandam janeti vāyamati vīriyam àrabhati cittam paggaṇhāti padahati ... vāyamati vìriyam àrabhati cittam paggaṇhäti padahati.

56 Vibh 236.

57 Ibid. 
foundations of mindfulness (cattāro satipattāna), recorded in several texts of the Tipitaka. ${ }^{58}$ As already mentioned above, the most well-known among them, positioned in modern Buddhism as the ur-text on mindfulness, is the Satipatthanasutta - a brief, succinct outline of the main aspects, areas and modes of mindfulness practise. The four satipatthannas articulate, describe or prescribe mindful contemplation in four areas: the body (kāya), feelings (vedana $)$, cognition (citta), and mental components (dhamma). The sequence of the four areas may indicate that the practise of mindfulness starts with the body, i.e. to a large extent at the conceptual level, and ends with the contemplation of dhammas at a non-conceptual level; although, as often underlined by modern scholars, all four areas are interlinked and may occur alternatively as objects of mindful practise (Anālayo 2006, 23-26). The last section of the Satipațthānasutta outlines mindfulness of dhammas, considered in the Abhidhammic analysis to be the fundamental components of experience (Nyanatiloka 2008, 244-6); however, the texts on the four satipatthānas do not list all dhammas that are listed and discussed in the Abbidhamma, but focus only on those that seem to be the most relevant or pivotal for the development of the awakening factors, facilitating the awakening. The presentation and structure of the four satipatthannas is interrelated and linked to the other main models of Buddhist teachings (i.e. the five aggregates, the formula of interdependent origination, the four truths), which are included in this sutta as objects of mindfulness, especially in the section on contemplation of mental components (dhammas). ${ }^{59}$

\section{Mindfulness in the Abhidhammapitaka}

In the Abhidhammapitaka, a collection of texts usually dated in the third century $\mathrm{BCE}$, the Buddhist doctrine is systematized and articulated and, unlike in the Suttapitaka, without the background narrative or references to historical context (Gethin 1998, 48). The Abhidhamma texts are concerned with the fundamental structure of Buddhist teachings, attempting to identify a "deep structure" of human experience. In this endeavour, the Abhidhamma follows, at least to some degree, structural models developed by the ancient Indian culture probably several centuries earlier, most notably in linguistics, such as the Pānini’’ Aștādhyāyz, a kind of structural-generative grammar, which establishes the fundamental (analytical and dynamic) structure of Sanskrit for description and generation

58 DN II 290-315; MN I 55-63; MN III 111-112; SN V 143, 294-297; AN III 450; Nidd1 1, 28, 63, 72, 78, 99; 340, 354, 370, 387; Nidd2 78, 124, 128; cf. Anālayo 2006, $28-30$.

59 E.g., mindful contemplation of the five aggregates (pañcakkhandha), twelve sense-spheres (saläyata$n a$ ), seven factors of awakening (bojjhainga), four truths (catusacca) (DN II 301-13; MN I 61-63). 
of the language in its many aspects and modes of expression. Similarly, the Abhidhamma texts systematically present the structure of Buddhist teachings, define key concepts and technical terminology, and analyse dynamics of human experience, always with the fundamental aim of the entire doctrine- the liberation from suffering. In terms of Western categories, the Abbidhamma is concerned mainly with the areas of philosophy, psychology, and ethics. It is a collection of seven texts with rather unclear chronology; according to the Buddhist tradition, the oldest text is the Dhammasangani ${ }^{60}$ followed by the Vibhanga and others. However, several modern scholars believe the Vibhanga to be the oldest (Frauwallner 1971, 69-121; Bronkhorst 1985, 305-20). These two texts dedicate considerable attention to mindfulness as one of the components of certain cognitive processes.

The Abhidhamma can be portrayed as a systematic articulation of all the main doctrinal models discussed above, i.e., the five aggregates (khandha), the formula of dependent origination (paticcasamuppäda), the eightfold path (atthaingiko maggo), the four foundations of mindfulness (cattāro satipattāna), and others. It aims to establish a cognitive structure, comprised of constituents that are the fundamental conditions for arising of interdependent momentary phenomena, which generate, condition or construct what we call "lived experience". In a systematic manner, it lists, defines and classifies the constituents, events or conditions, called dhammas, which underline and participate in the flow of mental and physical phenomena or events (Warder 1971, 272-95). It analyses their links and interdependence, and presents them as momentary, impermanent, without an intrinsic self or identity. Through the analysis of dhammas, the conceptual world is deconstructed; however, this analysis does not aim for a theoretical investigation or search for knowledge per se, motivated by curiosity, but has a rather distinct pragmatic goal, namely that of attaining knowledge or insight that brings deliverance from non-satisfactoriness $(d u k k h a)$, achieved through ethical development and meditation (Bodhi 1993, 4). The Abhidhamma provides theoretical premises that articulate, through well-defined terminology, primarily those constituents or events that are related to cultivation of ethics and meditation. Thus, the first book, the Dhammasangani, introduces in the very first sentence, like many other ancient Indian texts (e.g. the Yogasütra), the entire topic and aim of the Abhidhamma through the question: "Which dhammas are wholesome or ethically skilful (kusala)?"61 Then, with reference to ethics, the text presents various types of cognition (citta) which are listed, classified and analysed; more than half of them refer to higher stages of

60 Budddhaghosa lists the texts of the Abhidhamma in the following order: Dhammasangani, Vibhanga, Dhätukathā, Puggalapaññatti, Kathāvatthu, Yamaka, and Pațthāna (As 3, 21-23). 
concentration (jhāna), insight and nibbāna, indicating the pivotal role of meditation in the Buddhist path to liberation. ${ }^{62}$

Cognitive models, presented in the Abhidhamma, are comprised of very complex, interlinked structures which integrate analytic, synthetic and dynamic approaches. Here, only those features will be briefly outlined that are relevant for situating mindfulness within them. As mentioned earlier, the Abhidhamma represents the structure of cognitive processes or experiences from the fundamental, non-conceptual level through four basic categories, which are all called dhammas: cognition (citta), mental constituents (cetasika), materiality (rüpa) and nibbāna (Bodhi 1993, 25). The first three categories are viewed as momentary phenomena, impermanent, without intrinsic self, interrelated, conditioned and conditioning, whereas the last one, nibbanna, is unconditioned, beyond space and time. From an epistemological point of view, dhammas are the fundamental constituents or events of knowing; however, direct insight into their nature, links and conditionality can be achieved by penetrating beneath the conventional reality. Since dhammas are momentary, rapidly changing, and very subtle, they can be noted only when mindfulness and wisdom are well developed.

Cognition (citta) is the category characterised by knowing; it is defined as: "that which knows its object, which cognizes." ${ }^{33}$ At the conventional level cognition or consciousness (citta) seems continuous, whereas at the fundamental level (paramattha) it is considered to be constituted of a series of momentary cittas, which follow and condition one another so rapidly that they create an impression of continuity (Bodhi 1993, 29). Cognition (citta) does not occur on its own but always together with several mental components (cetasika) that determine, label, and affect the cognition of an object; in short, they determine how the objects of cognition are cognised or experienced. Cognition (citta) cannot occur without mental components (cetasika) and vice versa: they always arise together, are interlinked, momentary, impermanent, and conditioned; there is no reference point or observer outside this interlinked structure which is called lived experience. The Abhidhamma lists over fifty different mental constituents (cetasika), which occur in various groupings together with each citta, at every moment. ${ }^{64}$ Not all of them are compatible and thus cannot appear in the same group in a given moment of cognition; for example, anger or greed cannot occur in a group together with mindfulness or compassion.

62 Dhs 9-133.

63 As 63: Cittanti àrammaṇam cintetìti cittam vijānātìti attho.

64 Dhs 9,75-76; 87; 120. 
The Abbidhamma classifies, from an ethical perspective, ${ }^{65}$ different types of cognition (citta) in relation to the types of accompanying mental components (cetasikas) which can be ethically variable, unwholesome or wholesome. ${ }^{66}$ According to the Abbidhammattha Sangaha, there are thirteen cetasikas that are ethically variable, i.e. they can arise together within ethical or non-ethical cittas; among these, seven are "universal" cetasikas which arise with every citta. ${ }^{67}$ The non-ethical mental components (akusala cetasikas) arise in various combinations with unwholesome cognition (akusala citta) and are always accompanied by unpleasant mental feeling (domanassa); for example, in the moments of unethical cognition (akusala citta) there are always present delusion (moha) and restlessness (uddhacca), which can occur in different combinations with greed (lobha), conceit (māna), dullness (thīna), confusion (vicikicchä), or anger (dosa), envy (macchariya), selfishness (macchariya), etc. ${ }^{68}$ The largest number of cetasikas listed appear with ethical cognition (kusala citta), and mindfulness (sati) is one of them, occurring only in the "good company" of other wholesome or ethical cetasikas, such as trust (saddha), understanding of consequences (biri and ottap$p a)$, non-greed (alobha), non-aversion (adosa), mental equilibrium (tatramajjhattatā), peace (passaddhi), lightness (labutā), gentleness (mudutā), etc. ${ }^{69}$ Mindfulness is compatible with all other ethical cetasikas, such as compassion (karun $\bar{a})$, sympathetic joy (muditā), and equanimity (upekkhā), ${ }^{70}$ and incompatible with unethical (akusala) ones, such as greed, fear, and aversion. Thus the presence of mindfulness indicates and is indicated by other mental constituents (cetasikas) that arise with it, such as peace, trust, lightness, etc.

The Abhidhamma presents the processes of cognition as complex, ever-changing mental structures, comprised of sequences of rapid, extremely brief moments of cognition (citta) that appears in conjunction with many mental constituents (cetasika): these construct what we call lived experience. Mindfulness is one of the mental constituents: it arises in conjunction with other wholesome constituents

65 Therefore the title of first text from the Abbidhamapitaka, the Dhammasangani, is translated by Caroline Rhys Davids as A Buddhist Manual of Psychological Ethics (2012).

66 The first book of the Abhidhamma, the Dhammasangani (Dhs), comprises a detailed analysis of various types of cognition (citta), classified in reference to the mental components (cetasikas) which arise together with that particular type of citta.

67 The seven "universal" cetasikas are: contact (with an object) (phassa); feeling (vedanā); perception $($ sañ $\tilde{a})$; volition $($ cetanā); one-pointedness (ekaggatā); life faculty (jīvitindriya); and attention (manasikāra) (Cf. Bodhi 1993, 79).

68 Dhs 75-87.

69 Dhs 9.

70 Dhs 54-55. 
(cetasikas) ${ }^{71}$ and acts together with others as a required condition for the occurrence of wisdom (pañ na), which is an insight into the three characteristics ${ }^{72}$ of all phenomena and processes, leading to liberation from suffering ( $d u k k b a)$, to nibbāna. ${ }^{73}$

As outlined above, in the first book of the Abhidhamma, in the Dhammasangani, the typology and analysis of cognition (citta) and mental constituents (cetasika) are given, followed by the analysis of material components (rüpa) and their links with the first two categories. ${ }^{74}$ The following book, the Vibhanga, based on the analysis and structure given in the Dhammasaingani, focuses on the analysis of the main models of Buddhist doctrine, altogether eighteen in number, such as the five aggregates and the formula of dependent origination, and analyses them with different methods (Thittila 2010, xv-1xxi). It dedicates a whole section, the Satipatthanavibhainga, to the four foundations of mindfulness. However, the text differs, to some extent, in its structure and content from the Satipatthanasutta; ${ }^{75}$ it delineates the main areas of mindfulness and then analyses them according to the Abhidhamma, relating them to higher states of cognition. ${ }^{76}$ In the last and the largest book the Abhidhamma, the Patthana, the entire dynamics of cognitive processes is discussed in the light of the formula of interdependent origination. This is the most complete presentation of the interdependent conditionality, presented not through the twelve links but through twenty-four conditions, or modes of conditionality (paccaya), governing all the interrelated dhammas. ${ }^{77}$

To summarise, the Abhidhamma aims to identify, classify, characterise, and analyse all the constituents and conditions involved in Buddhist praxis, aiming for liberation from suffering (dukkha), and one of those conditions is the presence of mindfulness. It is considered that meditation generates insight and understanding that all the processes and phenomena comprising lived experience are without a permanent intrinsic nature, and that ignorance and clinging to them create an illusionary identity that is based on and perpetuates delusions and suffering $(d u k k h a)$.

71 The Abhidhammatthasangaha lists at least eighteen wholesome mental constituents (sobhanacetasika) which always occur together with mindfulnes; (cf. Bodhi 1993, 79).

72 The three characteristics are: impermanence (anicca), non-satisfactoriness (dukkba) and non-self (anattā).

73 MN III 245; SM II 32.

74 Dhs 125-79.

75 DN II 290-315; MN I 55-63.

76 Vibh 193-207.

77 This highly technical text is outside the scope of this paper; for an introduction to the text, see Ledi 1986. 
One of the required conditions for liberation from suffering is wisdom (pañña), which in turn is conditioned by mindfulness and other ethical components.

\section{Conclusion}

This paper defined the concept of mindfulness and presented its embedded nature in the main models of Buddhist doctrine as portrayed in the Pâli Canon. It was shown that, on its own, mindfulness could not be presented as a method of self-observation but is considered one of the constituents or conditions involved in cognitive processes, which, in conjunction with other (ethical) components, creates appropriate circumstances for the generation of insight and wisdom (pañ $\tilde{n} \bar{a})$. Since the basic presumption of Buddhism is that there is no intrinsic self, mindfulness cannot be interpreted as a kind of reference point or observer who witnesses phenomena and develops insights into the nature of experience. Buddhist meditation is primarily concerned with the nature (characterised by impermanence, no self, and non-satisfactoriness) and conditionality of cognitive processes; the cognition (citta) itself is also one of the momentary phenomena conditioning and being conditioned by these processes.

Mindfulness is regarded as a mental constituent that always appears only in the "good company" with other constituents and opens the door for wisdom (pañ $\tilde{a})$ to enter on the path to awakening. With the presence of wisdom, which is equated with insight that there is no permanent person or observer, contemplation enters the level of dhammas, viewed to be beyond the conceptual level. In Pāli sources, such meditation practice is called bhävanā, the term that may be rendered into English as "cultivation", referring to cultivation of ethical mental states and the seven factors of awakening (bojjhanga). ${ }^{78} \mathrm{~A}$ well-established mindfulness is accompanied by other components such as joy and tranquillity; however, these are not presented as the goal of practice. As frequently reiterated in the Tipitaka, the goal is the development of insight that all dhammas are empty of self (sabbe dhamma anattā $),{ }^{79}$ and this includes mindfulness, wisdom, the entire doctrine with its path and goals, and nibbāna.

78 The seven factors of awakening are: mindfulness (sati); investigation of dhamma (dhammavicaya); energy (viriya); joy (pìti); tranquility (passaddhi); concentration (samādhi); equanimity (upekkbā).

79 MN 1 230; AN I 286; S 3 133; Dhp 279. 


\section{Abbreviations}

Abbreviations and the quotation system of Pāli sources follow the Critical Pāli Dictionary (Epilegomena to vol. 1, 1948, pp. 5*-36*, and vol. 3, 1992, pp. II-VI). The numbers in the quotations of Palli sources refer to the volume and page of the PTS edition (e.g., MN I 21 refers to the Majjbima Nikayya, vol 1, p. 21)

AN Anguttaranikāya. [1885-1900] 1999-2013. Edited by R. Morris, E. Hardy. 5 vols. PTS.

As Atthasālinī. [1897] 2011. Edited by E. Müller, revised by L. S. Cousins. PTS.

DN Dighanikāya. [1890-1911] 1995-2007. Edited by T. W. Rhys Davids and J. E. Carpenter. 3 vols. PTS.

Dhs Dhammasangaṇi. [1885] 2001. Edited by Edward Müller. PTS.

KN Dhp Dhammapada. 1994. Edited by O. von Hinüber and K. R. Norman. PTS.

MN Majjbimanikāya. [1888-1902] 2013. Edited by V. Trenckner, R. Chalmers. 3 vols. PTS.

MW M. Monier-Williams, [1899] 1988. A Sanskrit-English Dictionary. Oxford: Oxford University Press. Reprinted, Delhi: Motilal Banarsidass.

Nidd I Mahāniddesa. [1916-1917] 2001. Edited by L. de la Vallée Poussin and E. J. Thomas. PTS.

Nidd II Cullaniddesa. [1918] 1988. Edited by W. Stede. PTS.

PED Päli-English Dictionary. 1921-1925. T. W. Rhys Davids and W. Stede. PTS.

Ps Papañcasūdanī, Majjhimanikāyātțhakathā of Buddhaghosa. [1922-1938] 1976-1979. Edited by J.H. Woods, D. Kośambi,I. B. Horner. 5 volsPTS.

SN Samyuttanikāya. [1884-1898] 1975-2006. Edited by L. Feer. 5 vols. PTS.

Vibh Vibhanga. [1904] 2003. Edited by C. A. F. Rhys Davids. PTS.

Vism Visuddhimagga. [1920-1921] 1975. Edited by C.A.F. Rhys Davids. PTS. 


\section{References}

Anālayo. 2006. Satipatthanna: The Direct Path to Realization. Selangor: Buddhist Wisdom Centre.

Bodhi, trans. 1993. Abhidhammattha Saingaha: A Comprehensive Manual of $A b-$ hidhamma: Pali Text, Translation and Explanatory Guide. Kandy: Buddhist Publication Society.

- 2000. The Connected Discourses of the Buddha: A New Translation of the Samyutta Nikàya. Boston: Wisdom Publications.

- 2012. The Numerical Discourses of the Buddha: A Translation of the Anguttara Nikàya. Boston: Wisdom Publications.

Braun, Erik. 2013. The Birth of Insight: Meditation, Modern Buddhism, and the Burmese Monk Ledi Sayadaw. Chicago and London: University of Chicago Press.

Bronkhorst, Johannes. 1985. "Dharma and Abhidharma." Bulletin of the School of Oriental and African Studies 48: 305-20.

Cox, Collett. 1992. "Mindfulness and Memory: The Scope of Smrti from Early Buddhism to the Sarvastivadin Abhidharma”. In In the Mirror of Memory: Reflections on Mindfulness and Remebrance in Indian and Tibetan Buddhism, edited by Janet Gyatso, 67-108. Albany: State University of New York.

Ditrich, Tamara. 2016. "Buddhism between Asia and Europe: The Concept of Mindfulness through an Historical Lens." Asian Studies 4 (1): 197-213.

Frauwallner, Erich. 1971. "Abhidharma-Studien: III. Abhisamayavādah, IV. Der Abhidharma der anderen Schulen." Wiener Zeitschrift für die Kunde Südasiens und Archiv für indische Philosophie 15: 69-121.

Gethin, Rupert. 1998. The Foundations of Buddhism. Oxford: Oxford University Press.

—. 2011. "On some Definitions of Mindfulness." Contemporary Buddhism 12 (1): 263-79.

Gyatso, Janet, ed. 1992. In the Mirror of Memory: Reflections on Mindfulness and Remebrance in Indian and Tibetan Buddhism. Albany: State University of New York.

Kabat-Zinn, Jon. 2003. "Mindfulness-Based Interventions in Context: Past, Present, and Future." Clinical Psychology: Science and Practice 10 (2): 144-56.

Kirmayer, Laurence J. 2015. "Mindfulness in Cultural Context.” Transcultural Psychiatry 52: 447-69.

Klaus, Konrad. 1992. "On the Meaning of the Root smr in Vedic Literature." Wiener Zeitschrift für Kunde Südasiens 36: 77-86.

Ledi. 1986. The Buddhist Philosophy of Relations: Pațthānudesa dīpanī. The Wheel Publication 331/333. Kandy: Buddhist Publication Society.

Nāṇamoli, trans. 1994. The Path of Purification (Visuddhimagga) by Bhantācariya Buddhaghosa. Kandy: Buddhist Publication Society. 
Nāṇanamoli, and Bodhi, trans. 1995. The Middle Length Discourses of the Buddha: A New Translation of the Majjhima Nikāya. Boston: Wisdom Publication.

Nyanatiloka. 2008. Guide through the Abhidhamma Pitaka. Fifth revised edition. Kandy: Buddhist Publication Society.

Rhys Davids, Caroline, trans. 2012. A Buddhist Manual of Psychological Ethics. PTS Translation Series 39. Bristol: Pali Text Society.

Sharf, Robert H. 1995. "Buddhist Modernism and the Rhetoric of Meditative Experience." Numen 42: 228-83.

Thittila, trans. 2010. The Book of Analysis (Vibhanga). PTS Translation Series 39, Bristol: Pali Text Society.

Tin, Pe Maung, trans. 2013. The Expositor (Atthasālinī). PTS Translation Series 8, 9. Bristol: Pali Text Society.

Warder, A. K. 1971. "Dharmas and Data.” Journal of Indian Philosophy 1: 272-95. 